\title{
Detection of Pathogenic and Non-pathogenic Bacteria in Drinking Water and Associated Biofilms on the Crow Reservation, Montana, USA
}

\section{Authors: Crystal L. Richards, Susan C. Broadaway, Margaret J. Eggers, John Doyle, Barry H. Pyle, Anne K. Camper, and Timothy E. Ford}

The final publication is available at Springer via http://dx.doi.org/10.1007/s00248-015-0595-6.

Richards, Crystal L. , Susan C. Broadaway, Margaret J. Eggers, John Doyle, Barry H. Pyle, Anne K. Camper, and Timothy E. Ford. "Detection of Pathogenic and Non-pathogenic Bacteria in Drinking Water and Associated Biofilms on the Crow Reservation, Montana, USA." Microbial Ecology 76, no. 1 (July 2018): 52-63. DOI:10.1007/s00248-015-0595-6. 


\title{
Detection of Mycobacteria, Legionella, and Helicobacter in Drinking Water and Associated Biofilms on the Crow Reservation, Montana, USA
}

\author{
Crystal L. Richards ${ }^{1}$, Susan C. Broadaway ${ }^{1}$, Margaret J. Eggers ${ }^{1,2}$, Emily Colgate ${ }^{3}$, John \\ Doyle ${ }^{4,5,6}$, Barry H. Pyle ${ }^{1}$, Anne K. Camper ${ }^{7 *}$, and Timothy E. Ford ${ }^{8}$ \\ ${ }^{1}$ Department of Microbiology and Center for Biofilm Engineering \\ Montana State University \\ Bozeman, MT 59717 \\ ${ }^{2}$ Little Big Horn College \\ Crow Agency, MT 59022 \\ ${ }^{3}$ University of Vermont \\ College of Medicine \\ Burlington, VT 05405 \\ ${ }^{4}$ Apsaalooke Water and Wastewater Authority \\ Hardin, Montana 59034 \\ ${ }^{5}$ Crow Tribal Member \\ Crow Agency, MT 59022 \\ ${ }^{6}$ Big Horn County Commissioner \\ Hardin, Montana 59034 \\ ${ }^{7}$ Department of Civil Engineering and Center for Biofilm Engineering \\ Montana State University \\ Bozeman, MT 59717 \\ ${ }^{8}$ Department of Research and Graduate Studies \\ University of New England \\ Biddeford, ME 04005 \\ Journal: Applied and Environmental Microbiology \\ Journal Section: Public Health
}

(*)Corresponding author. Mailing address:

Center for Biofilm Engineering,

Montana State University, EPS 366, Bozeman, MT 59717.

Phone: (406) 994-4906. Fax: (406) 994-6098. E-mail: anne_c@biofilm.montana.edu 
2 Public health has been shown to be directly related to water quality, and although drinking water

3 quality has improved in much of the United States, rural areas typically have underserved water

4 systems. Private residences in rural areas with water systems that are not adequately regulated,

5 monitored, and updated could have drinking water that poses a health risk. To investigate water

6 quality on the Crow Reservation in Montana, water and biofilm samples were collected from 57

7 public buildings and private residences served by both treated municipal and individual

8 groundwater well systems. Three bacterial genera, with members that are potential drinking

9 water pathogens, were chosen for investigation. Mycobacteria, Legionella, and Helicobacter

10 were detected by PCR and/or standard culture techniques. Free and total chlorine, temperature,

11 and $\mathrm{pH}$ were recorded at the time of sampling. Fecal coliform bacteria and heterotrophic plate

12 count (HPC) bacteria were enumerated using m-Coliblue $24^{\circledR}$ and R2A agar, respectively. All

13 three target genera were detected in drinking water systems on the Crow Reservation. Species

14 detected included the opportunistic and frank pathogens Mycobacterium avium, M. gordonae, M.

15 flavescens, Legionella pneumophila, and H. pylori. There was no correlation between the

16 presence of any genera and chlorine (free and total), temperature, $\mathrm{pH}$ or fecal coliforms.

17 However, there was an association between HPC bacteria and the presence of Mycobacteria and

18 Legionella but not the presence of Helicobacter. This research has shown that groundwater and

19 municipal drinking water systems and associated biofilms may be reservoirs for Mycobacteria,

20 Legionella, and Helicobacter.

21

22

23 
INTRODUCTION

25

26

27

In the United States over 15 million households rely on private ground water wells for their primary drinking water source (82), and in many rural areas private and community groundwater wells provide a major source of drinking water (12). Generally, most water obtained from private groundwater systems is considered safe to drink (23). However, in the United States from 1999-2002, 22\% of water-borne illnesses were attributed to individual water systems and 36\% were attributed to community systems (24). Private water systems are not routinely monitored for bacteriological water quality, thus little is known about the presence of bacterial pathogens in these systems. Information regarding water quality on Indian Reservations in the United States is equally scant. However, it is known that American Indian populations have disproportionately high disease burdens compared to the overall population of the United States (59). This is due to many factors which include economics, geographic isolation, cultural barriers, and inadequate sewage disposal (5).

The United States Centers for Disease Control report that chronic lower respiratory disease, influenza and pneumonia are among the top ten causes of death among American Indian and Alaska Native populations (82). In Montana, cancer is included as a major cause of death for American Indian populations (21). Although it has been observed that the disease burden of these populations is greater than the overall population of the United States (59), very little research has been done to identify causes and potential routes of exposure to infectious agents and environmental carcinogens. In the present study, three bacterial genera with members that are potential drinking water pathogens, Mycobacteria, Legionella, and Helicobacter, were chosen for investigation due to concerns expressed by Crow Tribal community members about 
46 poor drinking water quality and the relationship of these organisms to respiratory disease and

47 stomach cancer (28).

Mycobacteria are common inhabitants of drinking water systems and are known to

49 survive and proliferate in biofilms $(29,49)$. Several species of this genus cause respiratory

50 disease in mainly immunocompromised humans. Species include members of the

51 Mycobacterium avium complex, M. gordonae, $M$. flavescens, and others $(18,36,54,55)$.

52 Legionella are ubiquitous throughout aquatic environments including ground and surface water,

53 and manmade water reservoirs such as potable water systems and cooling towers. $(20,53,81)$.

54 Legionella pneumophila is the main causative agent for respiratory disease in that genus, causing

55 Legionellosis in the form of Legionnaire's disease and Pontiac fever (30). Legionellosis is

56 thought to occur when Legionella are aerosolized and inhaled (62). However, it has been

57 suggested that transmission of the different forms of Legionellosis, and the resultant severity of

58 disease, may be related to an association with biofilms (42). Helicobacter are pathogens of the

59 gastrointestinal tract of mammals but have been found in many environments such as well, river,

60 and pond water, in addition to house flies, and cattle feces (68). Helicobacter pylori are the

61 primary bacterial cause of gastritis, as well as peptic and duodenal ulcers in people around the

62 world (63). Infection is known to increase the risk of the development of gastric mucosa-

63 associated lymphoma and adenocarcinoma (62). Water is a short term reservoir, with the

64 pathogen often occurring sporadically in drinking water supplies that have been exposed to

65 sewage, or have been contaminated by infected animals (10).

66

Drinking water samples and their associated biofilms were tested for heterotrophic and

67 coliform bacteria by traditional culture methods. Mycobacteria, Legionella, and Helicobacter

68 species were detected by culture and PCR. The aim of this study was to investigate whether 
these organisms are common inhabitants of drinking water systems on the Crow Reservation in southeast Montana.

\section{MATERIALS AND METHODS}

Study Area. The Crow Indian Reservation, Montana, USA was the primary location for sample collection and analysis. Fifty-seven locations were sampled across the Crow Reservation (41 private residences and 14 public buildings) from March 2007 through July 2009. The Crow Reservation, the largest reservation in Montana, is rural with an average population density of 1.9 individuals per square mile (82). The Crow tribe has an enrolled membership of 11,357 and approximately $72 \%$ of members live on or near the Reservation (65). This Reservation has a diverse landscape spanning the Wolf, Big Horn and Pryor Mountain ranges, as well as the Big Horn and Little Big Horn River valleys. Land use is typical of rural areas in Montana with approximately $68 \%$ grazing rangeland, $12 \%$ dry cropland, $3 \%$ irrigated cropland, $15 \%$ forested areas, $1 \%$ wild land, and 1\% developed areas (4). The Crow Reservation area receives approximately 12-18 total inches annual precipitation (4). The surface water in the area is dependent on precipitation, snowpack and groundwater for recharge while the aquifers on the reservation rely on infiltration from rivers, streams, precipitation, stock ponds and reservoirs (38). The major township on the reservation, Crow Agency, has drinking water provided by treated surface water, while other townships utilize community and private groundwater wells and springs (33). The Crow Agency treatment facility performs reliably and adequately; however the distribution system in Crow Agency is nearly 100 years old and is vulnerable to cracks and leaks (27). Most of the residents outside of designated townships have privately maintained groundwater wells, often only drilled to first water. 
92 Sample Collection and Processing. Samples were primarily collected from kitchen sinks in private

93 residences and kitchen or restroom sinks in public buildings. Biofilm samples were collected first,

94 before any flushing or sterilization of the tap. Biofilm samples were collected by systematically

95 wiping the inside of the drinking water faucet with a sterile cotton swab before any flushing or

96 sterilization of the tap. Three swabs were collected from one faucet at each residence or building

97 and were placed in individual tubes containing sterile water for transport. To calculate surface area

98 of the biofilm, the faucet dimensions (depth and width) were measured and recorded. After biofilm

99 collection, the faucet was wiped with $95 \%$ ethanol to sanitize it before bulk water collection. After

100 sanitization of the tap, one liter of water was collected without flushing and is denoted as "first

101 flush". First flush sample collection was added in $2008(\mathrm{n}=20)$ and thus this fraction was only

102 analyzed for groundwater wells. After first flush collection, the water was run from the tap for two

103 minutes minimum or until water temperature stabilized prior to parameter measurement. Physical

104 and chemical characteristics were measured using standard methodologies. The presence and

105 quantity of free and total chlorine was measured using a colorimetric method (Hach kit model CN-

10670 chlorine test kit, Hach Co., Loveland, $\mathrm{CO}$ ). The temperature and $\mathrm{pH}$ were measured using a

107 multi-parameter probe (Oakton, Vernon Hills, IL). After a minimum of two minutes of flushing,

108 "post flush" water was collected in three separate one liter sterile plastic bottles. All samples were

109 placed on ice and transported to the laboratory and processed within $24 \mathrm{~h}$. In the laboratory, tubes

110 containing biofilm samples were vortexed for one minute and the cell suspensions from each swab

111 were pooled and mixed. Pooled cell suspensions from the same source were used for all biofilm

112 analysis. To concentrate water samples, $900 \mathrm{ml}$ from each liter sample was filtered through a 0.45

$113 \mu \mathrm{m} 25 \mathrm{~mm}$ diameter mixed cellulose ester filter (Pall Corp., Ann Arbor, MI). The filter was vortexed

114 in $1.5 \mathrm{ml}$ of PBS at maximum speed for one minute, and then removed and the cell suspension 
115 116

centrifuged at 13,000 $\mathrm{x}$ g for 10 minutes. The supernatant was removed and the cell pellet was resuspended in $100 \mu \mathrm{l}$ of sterile water. Pooled biofilm and both concentrated and un-concentrated water samples were used in DNA extractions. Pooled biofilm and un-concentrated water samples were used for genus specific culture methods.

Quantification of Fecal Indicator Bacteria and Heterotrophic Bacteria. Fecal indicator bacteria were quantified for first flush and post flush water samples using standard methodologies. The presence of fecal contamination was determined by growth on the selective and differential mColiblue $24^{\circledR}$ broth (Hach Co., Loveland, CO). This medium was used to culture coliform bacteria and differentiates Escherichia coli by using an enzymatic indicator. One hundred $\mathrm{ml}$ of each water sample and appropriate dilutions were filtered and the filter placed on a pad soaked with $2 \mathrm{ml}$ of the Coliblue $24^{\circledR}$ broth. The filters were incubated at $37^{\circ} \mathrm{C}$ and growth was observed at $24 \mathrm{~h}$. Post-flush water samples were collected in triplicate and each replicate was analyzed separately. Sterile water was filtered as a negative control, and sterile water was inoculated with environmental isolates of Escherichia coli and Klebsiella pneumoniae obtained from drinking water samples from New Haven, $\mathrm{CT}$ as a positive control. Heterotrophic bacteria were enumerated for biofilm, first flush and post flush samples. Each sample was diluted and plated on R2A agar followed by incubation at $30^{\circ} \mathrm{C}$ for 2 weeks.

Control Bacterial Strains and Growth Conditions. Representative species from each genus of interest were kept as frozen stocks at $-70^{\circ} \mathrm{C}$ and used as positive controls in both PCR and culture methods. The M. avium W2001 strain used in this study was originally isolated from drinking water in the Boston area and has been classified as M. avium subsp. hominisuis based on the hsp65 gene (80). The M. avium strain was cultured on Middlebrook $7 \mathrm{H} 10$ (Difco) and incubated at $37^{\circ} \mathrm{C}$ for 10 days. L. pneumophila strain 33153 was obtained from the American Type Culture Collection, 
138 cultured on Legionella agar (Difco) enriched with $0.7 \%$ L-cysteine and $0.3 \%$ ferric pyrophosphate 139 (Difco) and incubated at $37^{\circ} \mathrm{C}$ for 7 days. The H. pylori strain 43504 was obtained from the 140 American Type Culture Collection and was cultured on H. pylori specific HP medium (25). The 141 Helicobacter cultures were placed in a BBL anaerobe jar with a BBL CampyPak Plus ${ }^{\mathrm{TM}}$ sachet, 142 which creates a microaerophilic atmosphere of 5-10\% oxygen and 10\% carbon dioxide, and 143 incubated for one week at $37^{\circ} \mathrm{C}$. All control strains were grown and sequentially transferred twice 144 prior to use as positive controls.

145 Culture of Drinking Water and Biofilm Samples. The drinking water and biofilm samples were 146 analyzed for the presence of Mycobacteria, Legionella, and Helicobacter, by organism appropriate 147 culture techniques. Due to overgrowth by other micoorganisms, specific selection methods were 148 employed to target the organisms of interest. To select for members of the genus Mycobacteria, two 149 hundred microliters of each unconcentrated water sample as well as the pooled biofilm suspension 150 were treated with a final concentration of $0.005 \%$ cetyl pyridinium chloride (CPC) (Sigma, St. 151 Louis, MO) for 30 minutes as previously described (70). Sterile tap water was inoculated with $M$. 152 avium W2001 and treated with CPC as a positive control. The CPC treated cells were washed with 153 phosphate buffered saline twice by centrifuging at 10,000 x g for 5 minutes. Subsequently, one 154 hundred microliters were plated onto M7H10 agar (Difco), two replicates were plated for each 155 sample and were incubated at $37^{\circ} \mathrm{C}$ for up to three weeks. To select for Legionella species, each 156 sample was heated to $50^{\circ} \mathrm{C}$ for 30 minutes in a water bath (9). Subsequently, one hundred 157 microliters were plated onto enriched Legionella agar (Difco), two replicates were plated for each 158 sample and incubated at $37^{\circ} \mathrm{C}$ for one week. Sterile tap water was inoculated with L. pneumophila 159 ATCC 33153 and treated with heat as a positive control. The samples were also cultured on $H$. 160 pylori specific HP medium (25). H. pylori ATCC 43504 was inoculated into sterile water and 
161 plated as a positive control. The plates were placed in a BBL anaerobe jar with a BBL CampyPak 162 Plus ${ }^{\mathrm{TM}}$ sachet, and incubated for one week at $37^{\circ} \mathrm{C}$. All presumptive isolates were subcultured and 163 subsequently identified by PCR and phylogenetic analysis.

164 DNA Extraction from Biofilm and Water Samples. Nucleic acids were extracted from the pooled 165 biofilm suspensions and from concentrated and unconcentrated water samples. DNA was extracted 166 within $48 \mathrm{~h}$ of sampling and the extracts were immediately frozen at $-20^{\circ} \mathrm{C}$. Two $\mathrm{ml}$ of each biofilm 167 sample was centrifuged at $12,000 \mathrm{x}$ g for 15 minutes. Subsequently, all but $100 \mu$ l of the supernatant 168 was removed, the pellet was mixed thoroughly into the liquid and the suspension was added to $2 \mathrm{ml}$ 169 plastic screw cap tubes with o-rings (Fisher) containing $0.4 \mathrm{~g}$ of $0.1 \mathrm{~mm}$ sterile glass beads.

170 Similarly, $200 \mu 1$ of each concentrated and unconcentrated water sample was added to individual 171 sterile bead tubes for DNA extraction. Two hundred microliters of lysis buffer consisting of $20 \mathrm{mM}$ 172 sodium acetate (Fisher Scientific, Fair Lawn, New Jersey), 0.5\% sodium dodecyl sulfate (Fisher), 173 and $1 \mathrm{mM}$ ethylenediamine-tetraacetic acid (Fisher) and $500 \mu \mathrm{l}$ phenol (pH 8.1) (Fisher) was also 174 added to each $2 \mathrm{ml}$ tube and the mixture was homogenized in a Fastprep ${ }^{\circledR}$ FP120 cell disrupter at 175 speed 5.0 for 40 seconds. After homogenization, samples were placed on ice and allowed to rest for 17610 minutes. The samples were then centrifuged at $12,000 \mathrm{x} g$ for 10 minutes. The DNA was 177 precipitated by transferring the supernatant to a fresh $2 \mathrm{ml}$ tube containing an equal volume of 178 chloroform: isoamylalcohol (24:1). The samples were vortexed for 30 seconds and then centrifuged 179 at $12,000 \mathrm{x}$ g for 5 minutes. The supernatant was transferred to another fresh tube containing an 180 equal volume of isopropanol and $1 / 10$ volume of $3 \mathrm{M}$ sodium acetate and held at $-20^{\circ} \mathrm{C}$ for $24 \mathrm{~h}$. The 181 nucleic acids were subsequently pelleted by centrifugation, washed once with 70\% ethanol, air182 dried, and finally resuspended in $100 \mu 1$ of Tris-EDTA buffer (TE) consisting of 10mM Tris and $1831 \mathrm{mM}$ EDTA (Fisher). 
PCR Amplification, Sequencing, and Phylogenetic Analysis. The detection limit of each primer set was determined by amplification of a 10-fold dilution series of purified genomic DNA (10ng0.0001pg). The target genes, sequences, product sizes, and PCR conditions are listed in Table 1. To ensure that the PCR reaction was not inhibited by environmental contaminants, amplification of each sample was performed using eubacterial 16S rRNA primers as described by Voytek et al. (84). Amplification of the PCR products was done in $25 \mu 1$ PCR mixture containing 1x PCR buffer II, 50200ng template DNA, 200 $\mu \mathrm{M}$ (each) deoxynucleoside triphosphates (Takara Bio Inc., Japan), 0.1 $\mu \mathrm{M}$ (each) of primer (Integrated DNA Technologies, Coralville, IA), and 1U LA Taq polymerase (Takara). Aliquots of each PCR product were separated by electrophoresis in a $0.8 \%(\mathrm{w} / \mathrm{v})$ agarose gel (Fisher) in TBE buffer consisting of 90mM Tris- $\mathrm{HCl}$ (Fisher), $80 \mathrm{mM}$ boric acid (Fisher), $2.5 \mathrm{mM}$ EDTA (Fisher) and stained with ethidium bromide $(0.5 \mu \mathrm{g} / \mathrm{ml})$. PCR products were purified using the Qiaquick PCR purification kit (Qiagen, Valencia, CA) according to the manufacturer's instructions. Automated sequencing from both strands of PCR products of positive samples was performed by the Molecular Research Core Facility at Idaho State University. DNA sequences were assessed for their similarity to published DNA sequences using the BLAST database (http://www.ncbi.nlm.nih.gov/BLAST/). Sequences were aligned with ClustalW (77). Phylogenetic trees were constructed with the neighbor-joining method (67) and the Jukes-Cantor distance model (41) with bootstrap values of 1,000 replicates within MEGA v4.0 (75). All sequences were deposited in GenBank, accession numbers HQ018935-HQ018989.

Statistical Analysis. All data were compiled and for all instances where plate count values had a value of zero indicating none detected, a substitution rule was used (83). An arbitrary value (0.25) was chosen to replace all zero plate counts so that log transformations could be performed. Multiple linear regression and logistic regression tests were performed in Minitab ${ }^{\circledR}$ to determine correlations 
between $\mathrm{pH}$, temperature, drinking water and biofilm heterotrophic bacteria, total coliform bacteria, Helicobacter, Legionella and, Mycobacteria (44). Additionally, paired and Welch two sample t-tests were performed on heterotrophic and total coliform bacteria to determine if there were significant differences between first flush, post flush, and biofilm samples (44). Fisher's exact tests were performed to determine if the presence of Mycobacteria, Legionella, and/or Helicobacter had a relationship with each other (19). Fisher's exact tests were also done to determine if there was a relationship between Mycobacteria, Legionella, and Helicobacter and the source of the drinking water (treated municipal or groundwater well) (19). A Benjamini-Hochberg correction (10\%) was applied to all analyses to minimize false discovery due to multiple comparisons (11).

\section{RESULTS}

Physical Characteristics of Sampled Drinking Water. A total of 57 sites were sampled during this study. Sixteen samples were collected from public buildings and private residences that had drinking water supplied by treated municipal systems, while the 41 remaining systems were community and private groundwater wells. Total and free chlorine were quantified in drinking water sampled from municipal systems and ranged from none detected $-2.5 \mathrm{mg} / \mathrm{L}$ and none detected -1.3 $\mathrm{mg} / \mathrm{L}$ with means of $0.34 \mathrm{mg} / \mathrm{L}$ and $0.27 \mathrm{mg} / \mathrm{L}$, respectively. The $\mathrm{pH}$ of the drinking water ranged from 5.82-9.56 with a mean of 7.42. The temperature of the bulk water was recorded after flushing the tap and ranged from $8-33^{\circ} \mathrm{C}$ with a mean of $15.7^{\circ} \mathrm{C}$ and one outlier at $46^{\circ} \mathrm{C}$. Treated municipal systems had a mean temperature of $21.5^{\circ} \mathrm{C}$, while groundwater well systems had a mean temperature of $14.2^{\circ} \mathrm{C}$. Simple linear regression and logistic regression were used to analyze relationships between the measured physical characteristics and HPC bacteria, total coliforms, Legionella, 
Mycobacteria, and Helicobacter. No significant statistical correlation was detected between the measured physical characteristics and any of the bacteria identified.

\section{Detection of Heterotrophic Bacteria and Fecal Indicator Bacteria. Heterotrophic bacteria were} enumerated to assess whether these organisms were associated with the presence of potential pathogens. Table 2 shows the range and arithmetic mean of HPC bacteria in first flush, biofilm and post flush drinking water samples. The significance from the statistical analyses of the interactions between HPC bacteria counts and response variables are shown in Tables 3 and 4. Differences in the mean HPC populations between the first flush and post flush fractions collected were evaluated using Minitab ${ }^{\circledR}$ (Table 3). There was a significant difference in mean HPC bacteria when first flush and bulk water samples were compared $(P=0.025$, significant with Benjamini-Hochberg correction) with first flush samples having higher numbers of HPC bacteria on average. Differences in HPC bacteria between treated municipal and groundwater wells were also evaluated (Table 5). There was a difference between the mean HPC bacteria in biofilm samples and the drinking water source $(P=$ 0.049), however after applying the Benjamini-Hochberg correction this relationship was not significant. Overall, biofilm samples collected from groundwater wells had higher HPC bacteria counts than biofilm samples collected from treated municipal systems. There was not a significant difference in HPC bacteria numbers between the source water types for the post flush water samples. Total coliform bacteria were enumerated in first flush and post flush drinking water samples. Coliform bacteria were found in both treated municipal $(37.5 \%$ or $6 / 16)$ and untreated groundwater wells $(40 \%$ or $16 / 40)$ in post flush water samples. Escherichia coli was not observed in treated municipal samples but was found in $10 \%$ or $4 / 40$ of post flush groundwater well samples. Table 2 shows the range and arithmetic mean of coliform bacteria and E. coli in drinking water samples. Although there was a significant difference in HPC bacteria in first flush and post flush fractions, 
252 there was not a significant difference between mean coliform counts in first flush and post flush

253 fractions $(P>0.13)$. E. coli had a positive association with post flush HPC bacteria $(P=0.026$,

254 significant with correction) (Table 3).

255 Presence of Mycobacteria, Legionella, and Helicobacter. Mycobacterium species were detected in $25635.1 \%$ or $20 / 57$ of the locations sampled, with 15 found in the biofilm fraction, and 8 in the drinking 257 water fraction. Three of these occurrences of Mycobacteria were found in both the drinking water 258 and biofilm fractions. From the biofilm fractions, 7 of the 15 positive samples were identified by 259 PCR alone and 5 were identified by culture alone while 3 were identified by both PCR and culture. 260 From the drinking water fractions, 2 were identified by both PCR and culture while the remaining 6 261 were identified by PCR only. Fig. 1 shows the phylogenetic relatedness of the PCR and culture 262 isolates. The Mycobacterium species sequences detected were closely related to known species 263 including M. gilvum, M. mucogenicum, M. murale, M. flavescens, M. gordonae, M. manitobense and 264 members of the Mycobacterium avium complex (MAC) ( $>95 \%$ similarity).

To assess whether total coliforms or HPC bacteria influence the likelihood that Mycobacteria 266 may be present, logistic regression was applied in Minitab ${ }^{\circledR}$. Identical analyses were performed for 267 all three genera tested in this study. The analysis showed a relationship between Mycobacteria and 268 both post flush ( $P=0.044$, significant after correcting for multiple comparisons $)$ and biofilm HPC 269 bacteria ( $P=0.01$, not significant after corrections) (Tables 3 and 4 respectively). This showed that, 270 in general, as HPC bacteria increased, the odds of encountering Mycobacteria increased as well.

271 Mycobacteria were detected when Coliforms were present in 50\% or 10/20 of the locations sampled.

272 Of the 20 locations that tested positive for Mycobacteria, 8 were treated municipal systems and 12

273 were groundwater well systems. There were no significant relationships between the presence of 
274 Mycobacteria and total coliforms (logistic regression) or the source type of the drinking water 275 system (Fisher's exact test).

Legionella species were detected in $21 \%$ or 12 of the 57 locations sampled with 5 of those in

277 the biofilm fraction, 8 in the drinking water fraction and only one occurrence of Legionella in both

278 the biofilm and drinking water. Of the 5 positive biofilm samples, 3 were identified by PCR alone, 1

279 was identified by culture alone, and 1 was identified by both PCR and culture. From the 8 drinking 280 water samples, 2 were identified by both PCR and culture while the remaining 6 were identified by 281 PCR alone. Fig. 2 shows the phylogenetic relatedness of Legionella detected by PCR directly and 282 from culture isolates. The Legionella species detected include uncultured Legionella sp., $L$.

283 pneumophila, Legionella sp., L. fairfieldensis, and L. dresdeniensis (sequence similarity >95\%).

284 The results of the logistic regression showed a positive relationship between post flush HPC 285 bacteria counts and Legionella in the system $(P=0.003$, significant after correcting for multiple 286 comparisons) (Table 3). In general, as post flush HPC bacteria increased, the odds of encountering 287 Legionella increase as well. The greatest interaction occurred between Legionella detected in the 288 biofilm fraction and post flush HPC bacteria $(P=0.001)$. Legionella detected in the drinking water 289 fraction did not have a significant interaction $(P=0.068)$ with post flush fractions (Table 3$)$. There was no significant relationship between the presence of Legionella (in either the biofilm or drinking water fractions) and biofilm HPC bacteria (Table 4). Coliforms were present in 6 of the 12 samples 292 where Legionella were detected, but there was no significant relationship between the presence of 293 Legionella and total coliforms $(P=0.679)$. However, there was a significant association between 294 the presence of Legionella and E. coli $(P=0.018)$. Of the 12 samples positive for Legionella, 8 295 were at treated municipal sites and 4 were in groundwater. Unlike Mycobacteria, the source type of 
296 the drinking water system did have a relationship with the presence of Legionella $(P=0.002)($ Table 297 5).

Helicobacter species were detected in $7 \%$ or $4 / 57$ of locations sampled, with 2 of those in the biofilm and 2 in the drinking water. There were no occurrences of Helicobacter in the drinking water and biofilm concurrently. All of the positive samples were identified by PCR alone. Fig. 3

301 shows the phylogenetic relatedness of the Helicobacter sequences detected by PCR directly. The only Helicobacter species detected was H. pylori. Coliforms were found in 2 of the 4 samples where Helicobacter were detected. Logistic regression did not demonstrate any significant correlation between the presence of Helicobacter and any of the biological or physical parameters collected or the source type of the drinking water.

Interactions Between Potentially Pathogenic Genera. To determine whether there was a relationship between the presence of the three genera of interest a Fisher's exact test was performed. There was no statistically significant relationship between the three genera. Interestingly, $50 \%$ or 6/12 of locations positive for Legionella were also positive for Mycobacteria while only one location had both Legionella and Helicobacter. Conversely, there were 20 occurrences of Mycobacteria with 311 six of these samples also positive for Legionella $(28.5 \%)$ and two samples positive for Helicobacter 312 (9.5\%). Helicobacter was found alone in one location $(25 \%$ or $1 / 4)$.

The results of our study show that Mycobacteria, Legionella, and Helicobacter can be found in drinking water and associated biofilms on the Crow Reservation, in both treated municipal water

317 and untreated well water. The data also indicated that the number of HPC bacteria correlated with 318 the presence of Mycobacteria or Legionella. 
319 Fecal Coliforms and HPC Bacteria in Drinking Water. Although the presence of coliform

320 bacteria in drinking water is a potential indicator of fecal contamination and may indicate the

321 possible presence of harmful pathogens in drinking water (48), members of the coliform group

322 are also common inhabitants of rural drinking water systems (45). This study found that $40 \%$ of

323 community and private groundwater wells contained coliform bacteria while $37.5 \%$ of treated

324 municipal samples were positive. This is in agreement with an Iowa statewide rural well water

325 survey that found that $44 \%$ of private groundwater systems were contaminated with coliforms

326 (37). In our study area, surface water municipal and groundwater systems are vulnerable to

327 contamination, particularly during wet seasons that result in flooding events. These flooding

328 events can drastically increase the turbidity of surface waters and hinder water treatment,

329 potentially allowing coliform contamination of finished water. During March 2007, the largest

330 treatment facility on the Reservation was required to shut down due to mud and debris that

331 clogged the intake pipe after a flood (16). This particular event accounts for all of the coliform

332 positive municipal system samples except one, which occurred shortly after this flood. The

333 temporary closure of the treatment facility required a town-wide boil order and resulted in turbid

334 water at the tap. Groundwater wells in rural areas are vulnerable to flooding, but are also

335 susceptible to contamination from septic systems and inappropriate disposal of sewage effluents

336 and sludges (12). During sample collection, we occasionally observed instances where well

337 heads were completely inundated after precipitation, and water at the tap was turbid and/or

338 odiferous.

339 Coliform detection has inherent limitations and high levels of background bacteria can

340 interfere with the assays $(17,32,48)$. Coliform bacteria often do not adequately predict the

341 presence of pathogens, as has been demonstrated in waterborne outbreaks of Cryptosporidia, 
342 Giardia, and Salmonella (43). The lack of concurrence between the detection of Mycobacteria,

343 Legionella, and Helicobacter and coliforms indicates that fecal indicator bacteria have limited

344 use in predicting the presence of these environmental pathogens. Our finding agrees with that of

345 others who found no correlation between these organisms and fecal coliform bacteria $(61,72,84$, $34686)$.

Heterotrophic plate count bacteria are the normal flora of drinking water and include a

348 wide range of organisms including Acinetobacter, Aeromonas, Bacillus, Corynebacterium,

349 Pseudomonas, Mycobacteria, and Legionella (2). Helicobacter also utilize organic nutrients for

350 growth and thus fit the general definition of a heterotroph, but their microaerophilic lifestyle

351 make them less suited for growth in the drinking water environment $(1,35)$. This study has

352 shown that HPC bacteria can occur in numbers $>10^{6} \mathrm{CFU} / \mathrm{ml}$ and that water that was stagnant in

353 plumbing (first flush) had significantly greater numbers of HPC bacteria than water that has been

354 collected after flushing $(P=0.025)$. Water stagnation in drinking water pipes promotes bacterial

355 accumulation and may compromise microbiological quality of drinking water when those

356 organisms are flushed out (52). In this study, groundwater wells generally had higher levels of

357 HPC bacteria than treated municipal water, which can be at least partially explained by the

358 presence of chlorine residuals in municipal systems.

359 Heterotrophic plate count bacteria in biofilm and post flush drinking water fractions had 360 significant relationships with the presence of both Mycobacteria and Legionella. Logistic

361 regression showed that as the number of HPC bacteria increase, the odds of encountering

362 Mycobacteria or Legionella increase as well. The presence of Mycobacteria in the system had a

363 stronger relationship with HPC bacteria in post flush drinking water fractions (odds ratio 1.68, $P$

$364=0.044)$ than in biofilm fractions (odds ratio 0.63, $P=0.010$ ). The data showed a relationship 
365 between Mycobacteria identified in different fractions (biofilm and drinking water) and the

366 number of HPC bacteria in the different fractions. The most significant relationship was the

367 interaction between the presence of Mycobacteria in the drinking water and elevated HPC

368 bacteria in post flush water (odds ratio 2.05, $P=0.030$ ). September et al. (72) found that water

369 quality parameters do not provide any indication of the possible presence of Mycobacteria in

370 drinking water biofilms, while another group found a relationship between elevated HPC counts

371 and Mycobacteria in surface waters (39). The relationship between Mycobacteria and HPC in

372 drinking water systems remains unclear and more research is required to elucidate all of the

373 factors involved. The presence of Legionella in the system had a stronger relationship with HPC

374 bacteria in post flush drinking water (odds ratio $2.75, P=0.003$ ) than in biofilm samples (odds

375 ratio $0.77, P=0.185)$. The relationship between Legionella identified in biofilm and drinking

376 water and the number of HPC bacteria in the corresponding fractions was analyzed. Although

377 the minority of Legionella sequences were found in biofilm samples (41.6\%), they accounted for

378 the significant interaction with elevated HPC bacteria in post flush water. Finding elevated levels

379 of HPC bacteria in post flush samples significantly increased the odds of encountering

380 Legionella in a biofilm (odds ratio $31.66, \mathrm{P}=0.001$ ). There is very little data regarding the

381 usefulness of HPC counts for predicting the presence of Legionella. It has been shown that

382 certain common HPC bacteria inhibit the growth of Legionella while others stimulate it (79).

383 Our data is in agreement with LeChevallier et al. (47) who concluded that HPC bacteria were

384 useful for predicting the presence of opportunistic pathogens and provide insight into the overall

385 quality of drinking water. There was no relationship between HPC bacteria and the presence of

386 Helicobacter in any fraction. 

research has attempted to identify the presence of potential pathogens and identify factors that may play a role in where and when these organisms may be present. Because the residents on the Crow Reservation were concerned with overall drinking water quality, samples of drinking water and associated biofilms were taken at public buildings and private residences. This resulted in samples being collected from treated municipal and untreated groundwater systems. In this study, biofilm samples were collected in addition to drinking water samples according to the recommendations for Legionella (VAMC; Pittsburgh, Pa., CDC; Atlanta, Ga.). Although this recommendation specifically addresses Legionella detection, it is in agreement with many other findings that Mycobacteria, Legionella, and Helicobacter can be harbored and detected in

397 drinking water biofilms $(35,69,74)$. Finally, two methods for detecting the organisms of interest, PCR and culturing, were chosen. It is well documented that traditional culturing techniques underestimate the quantity and diversity of microorganisms in the environment (60). However, when looking at issues of public health it is also important to identify whether these organisms are viable and perhaps capable of infection. By combining molecular detection with traditional culturing methods, it is possible to increase the likelihood of detecting an organism of 403 interest. Mycobacteria, Legionella, and Helicobacter were found in both treated municipal water and untreated well water systems. Mycobacteria were found more often in groundwater systems 406 than in treated municipal systems $(61.9 \%$ and $38.1 \%$ of the 20 samples positive for 407 Mycobacteria, respectively). Reports of the detection of Mycobacteria in groundwater have 408 been sporadic, but generally have shown relative frequencies from not detected to up to $68 \%$ of 409 locations testing positive $(46,71)$. Mycobacteria have been detected in treated systems with 
410 varying results as well $(22,46,78)$. Overall, our results are consistent with other reports of

411 Mycobacteria in treated municipal and groundwater systems. Unlike Mycobacteria, Legionella

412 had a statistically significant relationship with the source of the drinking water. Legionella were

413 found more often in treated municipal systems $(66.7 \%)$ than in groundwater systems $(33.3 \%)$. In

414 other studies, Legionella has been frequently found in municipal water systems and sporadically

415 in groundwater $(14,20,53,87)$. It has been shown that the presence and diversity of Legionella

416 varies spatially in drinking water distribution systems and in groundwater (87). It is possible that

417 premise plumbing in buildings with light or sporadic use could promote the planktonic and/or

418 necrotrophic growth of Legionella as described by others $(51,76)$. It is also likely that the

419 overall warmer temperature of the treated municipal system is supportive for Legionella survival

420 and growth. Helicobacter were detected in 4 locations of our study area with $50 \%$ in treated

421 municipal systems and 50\% in untreated groundwater systems. One of the instances of

422 Helicobacter occurred during the flood event that closed the water treatment facility for a short

423 period of time. Reports of Helicobacter detection in drinking water have been intermittent with

424 most reports finding infrequent positive samples $(15,40,85)$. Although the environmental

425 reservoir of Helicobacter is unknown, it is possible that water distribution systems may be

426 vulnerable to contamination through breaks or leaks in distribution pipes. Groundwater systems

427 that are too shallow may be under the influence of surface water which could be contaminated by

428 agricultural practices and inadequate sewage disposal (12).

429 Mycobacteria, Legionella, and Helicobacter were detected in both biofilm and drinking

430 water samples. Mycobacterium gilvum and M. avium complex were most frequently identified

431 ( $>95 \%$ sequence similarity) and were both found in biofilms more often than drinking water.

432 Legionella pneumophila occurred more often in biofilm samples while sequences identified as 
433 Legionella sp. were more often identified in drinking water samples. Interestingly, both

434 Mycobacteria and Legionella had greater rates of culture positive tests in biofilm samples. This

435 could indicate that tap water biofilms are protective and supportive for these organisms. H. pylori

436 sequences occurred in two drinking water samples and two biofilm samples. Although H. pylori

437 were not detected in a large number of locations, biofilm sampling doubled the detection of this

438 organism. These data are consistent with reports of others that indicate that all three of these

439 genera can be found in both drinking water and associated biofilm samples $(50,53)$.

440

Consistent with other reports, molecular detection of all three genera was more successful

than traditional culture methods $(3,49,73,85)$. The majority of detections were achieved by PCR,

442 with only a small fraction of the samples positive for Mycobacteria and Legionella culture isolates.

443 While it is known that molecular techniques are important for detecting organisms that are injured,

444 or viable but not culturable $(1,7)$, culture techniques provide valuable information as well. In this

445 study, both Mycobacteria and Legionella were detected by culture methods and PCR. However, in a

446 minority of cases, culture positive locations could not be identified by PCR performed directly on

447 the samples. This has been documented by others as well and could be due to PCR inhibitors, such

448 as heavy metals, intrinsic to the drinking water system $(31,66)$.

449 Health Consequences of Mycobacteria, Legionella, and Helicobacter in Drinking Water. All of

450 the Mycobacteria sequences detected in this study were of the nontuberculous Mycobacteria group

451 (NTM). One important detected NTM are the slow-growing opportunistic pathogens in the $M$.

452 avium complex (MAC), which includes the M. avium subsp. avium, M. avium subsp. intracellulare,

453 M. avium subsp. hominisuis, and M. avium subsp. paratuberculosis (64). MAC accounts for over 70

454 percent of nontuberculous mycobacterial disease in the United States and for more than 95 percent

455 of nontuberculous disease among persons infected with human immunodeficiency virus (HIV) (64). 
456 It has been shown that MAC isolates recovered from hospital water had a close relationship (large-

457 restriction-fragment pattern analysis) with clinical isolates recovered from patients indicating that

458 water could be the reservoir for infection (6). Other sequences identified in this study were of $>95 \%$

459 similarity to M. gordonae, M. flavescens, and M. mucogenicum. These species are all known to be

460 inhabitants of drinking water systems and have been implicated in adverse health consequences (36,

$46146,54,55)$. One interesting fast-growing Mycobacterium species that we encountered fairly

462 frequently was $M$. gilvum. This bacterium is an environmental mycobacterium that has been isolated

463 from soils in Montana (57), which is known to degrade polyaromatic hydrocarbons and has not been

464 implicated in any health effects.

465 The Legionella species sequences detected in this study were mainly L. pneumophila and

466 Legionella sp. but also included sequences similar to L. fairfieldensis, L. dresdeniensis, and L.

467 birminghamiensis. L. pneumophila is a well-documented opportunistic pathogen that has a low

468 infection rate (1-6\%), but a mortality rate of $10-15 \%$, and accounts for $1-4 \%$ of all pneumonia cases

469 in the United States' general population (62). L. pneumophila is the primary disease causing species

470 of this genus but there have been occasional cases of disease caused by other Legionella sp. (58).

471 Other Legionella species such as L. fairfieldensis and L. birminghamiensis have been documented in

472 drinking water systems (26), but are not implicated in health effects.

473 This study detected H. pylori sequences at four of the locations sampled. Recent research

474 using the ${ }^{13} \mathrm{C}$ urea breath test has shown that the prevalence of $H$. pylori in one rural community of

475 Montana is greater than 50\% (56). Their research also indicated that the presence of $H$. pylori

476 infection was associated with regular consumption of city water as indicated by questionnaire results

477 (Unpublished data, USEPA) (56). Untreated well water has also been implicated in clinical 
478 infections in the United States $(8,10)$. Areas with poor water quality may be more likely to have

479 higher rates of water-borne transmission of disease, especially in children $(15,85)$.

In conclusion, microbes such as M. avium, L. pneumophila, and H. pylori can be found in

481 drinking water systems in rural underserved areas. Coliforms were shown to be inadequate indicators

482 for all of these organisms, while HPC bacterial levels did have a relationship with the presence of

483 Mycobacteria and Legionella. Both treated municipal water and groundwater fed systems can harbor

484 these organisms, which can be found in both bulk water and associated biofilms. Consequently, it is

485 impossible to rule out drinking water as a route of infection for pathogenic bacteria such as $M$.

486 avium, L. pneumophila, and H. pylori. To address health disparities in underserved communities

487 such as American Indian reservations it is important to determine potential reservoirs of infection.

488 These results are pertinent to water utility managers, regulatory agencies, as well as epidemiologists

489 interested in identifying disease causing agents in rural drinking water systems.

490

491

\section{ACKNOWLEDGEMENTS}

The authors would like to thank the entire Crow Environmental Health Steering

493 Committee, Ada Bends, Urban Bear Don't Walk, John Doyle, Brandon Goodluck, Vernon Hill,

494 Larry Kindness, Myra Lefthand, Henry Pretty On Top, Ronald Stewart, and Sara Young, for

495 providing insight into research in reservation communities and community support for this work.

496 Thanks to Crow community coordinators, Crescentia Cummins and Gail Whiteman, without

497 whom sample collection would not have been possible. Additional thanks to Al Parker for

498 statistical support.

This work was supported by the National Institute for Health, Center for Native Health

500 Partnerships, (M201-10-W2724). Dr. Ford is supported in part by a grant from the U.S. 
501 Environmental Protection Agency's Science to Achieve Results (US-EPA STAR) program and

502 Crystal Richards is supported by a US-EPA STAR Fellowship. Although the research described

503 in the article has been funded in part by the U.S. Environmental Protection Agency's STAR

504 program through grant numbers RD833706 and FP916936, it has not been subjected to any EPA

505 review and therefore does not necessarily reflect the views of the Agency, and no official

506 endorsement should be inferred.

507

508

REFERENCES

509 1. Adams, B. L., T. C. Bates, and J. D. Oliver. 2003. Survival of Helicobacter pylori in a 510 natural freshwater environment. Appl. Environ. Microbiol. 69:7462-7466.

511 2. Allen, M. J., S. C. Edberg, and D. J. Reasoner. 2004. Heterotrophic plate count 512 bacteria - what is their significance in drinking water? Int. J. Food Microbiol. 92:265$513 \quad 274$.

514 3. Angenent, L. T., S. T. Kelley, A. St Amand, N. R. Pace, and M. T. Hernandez. 2005.

515 Molecular identification of potential pathogens in water and air of a hospital therapy 516 pool. Proc. Natl. Acad. Sci. U.S.A. 102:4860-4865.

517 4. Anonymous. 2002. Crow Indian Reservation Natural, Socio-Economic, and Cultural 518 Resources Assessment and Conditions Report, Crow Tribe of Indians, Montana.

519 5. Anonymous. 1999. The Health Care Challenge: Acknowledging Disparity, Confronting 520 Discrimintaion, and Ensuring Equality. United States National Archives and Records 521 Administration, Washington D.C. 20402.

522 6. Aronson, T., A. Holtzman, N. Glover, M. Boian, S. Froman, O. G. W. Berlin, H. Hill, 523 and G. Stelma. 1999. Comparison of large restriction fragments of Mycobacterium 
avium isolates recovered from AIDS and non-AIDS patients with those of isolates from potable water. J. Clin. Microbiol. 37:1008-1012.

Atlas, R. M. 1999. Legionella: from environmental habitats to disease pathology, detection and control. Environ. Microbiol. 1:283-293.

8. Baker, K. H., and J. P. Hegarty. 2001. Presence of Helicobacter pylori in drinking water is associated with clinical infection. Scand. J. Infect. Dis. 33:744-746.

9. Bartie, C., S. N. Venter, and L. H. Nel. 2003. Identification methods for Legionella from environmental samples. Water Res. 37:1362-1370.

10. Bellack, N. R., M. W. Koehoorn, Y. C. MacNab, and M. G. Morshed. 2006. A conceptual model of water's role as a reservoir in Helicobacter pylori transmission: a review of the evidence. Epidemiol. Infect. 134:439-449.

11. Benjamini, Y., and Y. Hochberg. 1995. Controlling the false discovery rate - a practical and powerful approach to multiple testing. J. R. Stat. Soc. Series B Stat. Methodol. 57:289-300.

12. Bitton, G., and C. P. Gerba. 1984. Groundwater Pollution Microbiology: the Emerging Issue, p. 1-7. In G. Bitton and C. Gerba (ed.), Groundwater pollution microbiology. John Wiley \& Sons, New York.

13. Boddinghaus, B., T. Rogall, T. Flohr, H. Blocker, and E. C. Bottger. 1990. Detection and Identification of Mycobacteria by Amplification of RNA. J. Clin. Microbiol. 28:1751-1759.

14. Brooks, T., R. A. Osicki, V. S. Springthorpe, S. A. Sattar, L. Filion, D. Abrial, and S. Riffard. 2004. Detection and identification of Legionella species from groundwaters. J. Toxicol. Environ. Health. 67:1845-1859. 
547 15. Bunn, J. E. G., W. G. MacKay, J. E. Thomas, D. C. Reid, and L. T. Weaver. 2002.

548

549

550

551

552

553

554

555

556

557

558

559

560

561

562

563

564

565

566

567

568

569

Detection of Helicobacter pylori DNA in drinking water biofilms: implications for transmission in early life. Lett. Appl. Microbiol. 34:450-454.

16. Burkland, B. 2010. Personal Communication regarding treatment facility at Crow Agency, US Environmental Protection Agency. Helena, MT.

17. Burlingame, G. A., J. McElhaney, M. Bennett, and W. O. Pipes. 1984. Bacterial interference with coliform colony sheen production on membrane filters. Appl. Environ. Microbiol. 47:56-60.

18. Cassidy, P. M., K. Hedberg, A. Saulson, E. McNelly, and K. L. Winthrop. 2009. Nontuberculous Mycobacterial Disease Prevalence and Risk Factors: A Changing Epidemiology. Clin. Infect. Dis. 49:E124-E129.

19. Conover, W. J. 1999. Practical nonparametric statistics, Third ed. Elm Street Publishing Services, Inc., New York.

20. Costa, J., I. Tiago, M. S. da Costa, and A. Verissimo. 2005. Presence and persistence of Legionella spp. in groundwater. Appl. Environ. Microbiol. 71:663-671.

21. Covers Up, T., R. Turnsplenty, D. Wetzel, and J. Giroux. 2005. 1990-2002 Montana and Wyoming American Indian Top Ten Causes of Death. Rocky Mountain Tribal Epidemiology Center.

22. Covert, T. C., M. R. Rodgers, A. L. Reyes, and G. N. Stelma. 1999. Occurrence of nontuberculous mycobacteria in environmental samples. Appl. Environ. Microbiol. 65:2492-2496.

23. Craun, G. F., R. L. Calderon, and T. J. Wade. 2006. Assessing waterborne risks: an introduction. J. Water Health 04. Suppl 2:3-18. 
570 24. Craun, M. F., G. F. Craun, R. L. Calderon, and M. J. Beach. 2006. Waterborne

571 outbreaks reported in the United States. J. Water Health 04. Suppl 2:19-30.

572 25. Degnan, A. J., W. C. Sonzogni, and J. H. Standridge. 2003. Development of a plating

573 medium for selection of Helicobacter pylori from water samples. Appl. Environ.

$574 \quad$ Microbiol. 69:2914-2918.

575 26. Diederen, B. M. W., C. M. A. de Jong, I. Aarts, M. F. Peeters, and A. van der Zee. 576 2007. Molecular evidence for the ubiquitous presence of Legionella species in Dutch tap water installations. J. Water Health 5:375-383.

578 27. Doyle, J. 2010. Personal communication regarding municipal distribution system at Crow Agency, Crow Environmental Health Steering Committee. Crow Agency, MT.

$580 \quad$ 28. Doyle, J., L. Kindness, U. Bear Don't Walk, S. Young, and M. Lefthand. 2006. Personal communication regarding water quality on Crow Reservation, Crow Environmental Health Steering Committee. Crow Agency, MT.

29. Falkinham, J. O., C. D. Norton, and M. W. LeChevallier. 2001. Factors influencing numbers of Mycobacterium avium, Mycobacterium intracellulare, and other mycobacteria in drinking water distribution systems. Appl. Environ. Microbiol. 67:12251231.

587 30. Fields, B. S., R. F. Benson, and R. E. Besser. 2002. Legionella and Legionnaires' disease: 25 years of investigation. Clin. Microbiol. Rev. 15:506-526.

589 31. Fiume, L., M. A. Bucca Sabattini, and G. Poda. 2005. Detection of Legionella 590 pneumophila in water samples by species-specific real-time and nested PCR assays. Lett. Appl. Microbiol. 41:470-475. 
592 32. Franzblau, S. G., B. J. Hinnebusch, L. M. Kelley, and N. A. Sinclair. 1984. Effect on 593 noncoliforms on coliform detection in potable groundwater - improved recovery with an anaerobic membrane-filter technique. Appl. Environ. Microbiol. 48:142-148.

595 33. Geach, J. 2007. Source Water Delineation and Assessment Report, p. 1-34. United States 596 Environmental Protection Agency, Helena, MT.

597 34. Germani, Y., C. Dauga, P. Duval, M. Huerre, M. Levy, G. Pialoux, P. Sansonetti, 598 and P. A. D. Grimont. 1997. Strategy for the detection of Helicobacter species by 599

600 amplification of 16S rRNA genes and identification of $H$. felis in a human gastric biopsy. Res. Microbiol. 148:315-326.

601 35. Giao, M. S., N. F. Azevedo, S. A. Wilks, M. J. Vieira, and C. W. Keevil. 2008.

602 Persistence of Helicobacter pylori in heterotrophic drinking-water biofilms. Appl. $603 \quad$ Environ. Microbiol. 74:5898-5904.

604 36. Guillen, S. M., J. S. Hospital, E. G. Mampaso, A. G. Espejo, C. E. Baquedano, and 605 A. O. Calderon. 1986. Gluteal abscess caused by Mycobacterium flavescens. Tubercle 606 67:151-153.

607 37. Hallberg, G. R., and B. C. Kross. 1990. Iowa Statewide Rural Well Water Survey 608 609 610 Summary of Results. Iowa Department of Natural Resources Geologocal Survey Bureau and University of Iowa Center for Health Effects of Environmental Contamination, Iowa City, IA 52242

611 38. Heath, R. C. 1984. Ground-Water Regions of the United States, p. 1-78. U.S. Geological 612 Survey Supply Paper 2242. 
613 39. Iivanainen, E. K., P. J. Martikainen, P. K. Vaananen, and M. L. Katila. 1993.

614 Environmental factors affecting the occurrence of mycobacteria in brook waters. Appl.

615 Environ. Microbiol. 59:398-404.

616 40. Janzon, A., A. Sjoling, A. Lothigius, D. Ahmed, F. Qadri, and A. M. Svennerholm.

617 2009. Failure To Detect Helicobacter pylori DNA in Drinking and Environmental Water

618 in Dhaka, Bangladesh, Using Highly Sensitive Real-Time PCR Assays. Appl. Environ.

$619 \quad$ Microbiol. 75:3039-3044.

620 41. Jukes, T. H., and C. R. Cantor. 1969. Evolution of protein molecules, p. 21-132. In H.

621 N. Munro (ed.), Mammalian protein metabolism. Academic Press, New York.

622 42. Kramer, M. H., and T. E. Ford. 1994. Legionellosis: ecological factors of an

623 environmentally 'new' disease. Zentralbl Hyg Umweltmed 195:470-82.

624 43. Kramer, M. H., B. L. Herwaldt, R. L. Calderon, and D. D. Juranek. 1996.

625 Surveillance for Waterborne-Disease Outbreaks -- United States, 1993-1994, p. 1-33, vol.

626 45. Centers for Disease Control, Washington D.C.

627 44. Kutner, M., C. Nachtsheim, J. Neter, and W. Li. 2004. Applied linear statistical

628 models, Fifth ed. McGraw-Hill/Irwin, New York.

629 45. Lamka, K. G., M. W. LeChevallier, and R. J. Seidler. 1980. Bacterial contamination 630 of drinking water supplies in a modern rural neighborhood. Appl. Environ. Microbiol. $631 \quad 39: 734-738$.

632 46. Le Dantec, C., J. P. Duguet, A. Montiel, N. Dumoutier, S. Dubrou, and V. Vincent. 633 2002. Occurrence of mycobacteria in water treatment lines and in water distribution systems. Appl. Environ. Microbiol. 68:5318-5325. 
47. LeChevallier, M. W., R. J. Seidler, and T. M. Evans. 1980. Enumeration and characterization of standard plate-count bacteria in chlorinated and raw water supplies. Appl. Environ. Microbiol. 40:922-930.

48. Leclerc, H., D. A. A. Mossel, S. C. Edberg, and C. B. Struijk. 2001. Advances in the bacteriology of the coliform group: their suitability as markers of microbial water safety. Annu. Rev. Microbiol. 55:201-234.

49. Lehtola, M. J., E. Torvinen, J. Kusnetsov, T. Pitkanen, L. Maunula, C. H. von Bonsdorff, P. J. Martikainen, S. A. Wilks, C. W. Keevil, and I. T. Miettinen. 2007. Survival of Mycobacterium avium, Legionella pneumophila, Escherichia coli, and caliciviruses in drinking water-associated biofilms grown under high-shear turbulent flow. Appl. Environ. Microbiol. 73:2854-2859.

50. Mackay, W. G., L. T. Gribbon, M. R. Barer, and D. C. Reid. 1998. Biofilms in drinking water systems - A possible reservoir for Helicobacter pylori. Water Sci. Technol. 38:181-185.

51. Mampel, J., T. Spirig, S. S. Weber, J. A. J. Haagensen, S. Molin, and H. Hilbi. 2006. Planktonic replication is essential for biofilm formation by Legionella pneumophila in a complex medium under static and dynamic flow conditions. Appl. Environ. Microbiol. 72:2885-2895.

52. Manuel, C. M., O. C. Nunes, and L. F. Melo. 2010. Unsteady state flow and stagnation in distribution systems affect the biological stability of drinking water. Biofouling 26:129-139. 
656 53. Marciano-Cabral, F., M. Jamerson, and E. S. Kaneshiro. 2010. Free-living amoebae,

657

658

659

660

661

662

663

664

665

666

667

668

669

670

671

672

673

674

675

676

677

678

Legionella and Mycobacterium in tap water supplied by a municipal drinking water facility. J. Water Health 08:71-82.

54. Marshall, C., J. Samuel, A. Galloway, and S. Pedler. 2008. Mycobacterium mucogenicum from the Hickman line of an immunocompromised patient. J. Clin. Pathol. 61:140-141.

55. Mazumder, S. A., A. Hicks, and J. Norwood. 2010. Mycobacterium gordonae pulmonary infection in an immunoocompetent adult. N. A. J. Med. Sci. 2:205-207.

56. Melius, E., R. Wierzba, S. Davis, J. Sobel, B. Gold, A. Henderson, and J. Cheek. 2005. Risk factors for Helicobacter pylori in a rural community.

57. Miller, C. D., R. Child, J. E. Hughes, M. Benscai, J. P. Der, R. C. Sims, and A. J. Anderson. 2007. Diversity of soil mycobacterium isolates from three sites that degrade polycyclic aromatic hydrocarbons. J. Appl. Microbiol. 102:1612-1624.

58. Muder, R. R., and V. L. Yu. 2002. Infection due to Legionella species other than L. pneumophila. Clin. Infect. Dis. 35:990-998.

59. National Center for Health Statistics. 2010. Health, Unites States, 2009: With Special Feature on Medical Technology., Hyattsville, MD.

60. Pace, N. R. 1997. A molecular view of microbial diversity and the biosphere. Science 276:734-740.

61. Palmer, C. J., G. F. Bonilla, B. Roll, C. Paszkokolva, L. R. Sangermano, and R. S. Fujioka. 1995. Detection of Legionella species in reclaimed water and air with the ENVIROAMP Legionella PCR kit and direct fluorescent-antibody staining. Appl. Environ. Microbiol. 61:407-412. 
679 62. Percival, S., R. Chalmers, M. Embrey, P. Hunter, J. Sellwood, and P. Wyn-Jones.

680 2004. Microbiology of Waterborne Diseases. Elsevier Academic Press, California.

681 63. Perez-Perez, G. I., D. Rothenbacher, and H. Brenner. 2004. Epidemiology of

682 Helicobacter pylori infection. Helicobacter 9:1-6.

683 64. Reed, C., C. F. von Reyn, S. Chamblee, T. V. Ellerbrock, J. W. Johnson, B. J.

684 Marsh, L. S. Johnson, R. J. Trenschel, and C. R. Horsburgh. 2006. Environmental

685 risk factors for infection with Mycobacterium avium complex. Am. J. Epidemiol. 164:32-

68640.

687 65. Research and Analysis Bureau. 2008. Demographic and Economic Information for the

688 Crow Reservation, p. 1-8. Montana Department of Labor and Industry, Helena, MT

68959624.

$690 \quad$ 66. Riffard, S., S. Douglass, T. Brooks, S. Springthorpe, L. G. Filion, and S. A. Sattar.

691 2001. Occurrence of Legionella in groundwater: an ecological study. Water Sci. Technol.

$692 \quad 43: 99-102$.

693 67. Saitou, N., and M. Nei. 1987. The neighbor-joining method - a new method for

694 reconstructing phylogenetic trees. Mol. Biol. Evol. 4:406-425.

695 68. Sasaki, K., Y. Tajiri, M. Sata, Y. Fujii, F. Matsubara, M. G. Zhao, S. Shimizu, A.

696 Toyonaga, and K. Tanikawa. 1999. Helicobacter pylori in the natural environment.

697 Scand. J. Infect. Dis. 31:275-280.

698 69. Schulze-Robbecke, R., B. Janning, and R. Fischeder. 1992. Occurrence of

699

mycobacteria in biofilm samples. Tuber. Lung Dis. 73:141-144. 
700 70. Schulze-Robbecke, R., A. Weber, and R. Fischeder. 1991. Comparison of

701 decontamination methods for the isolation of mycobacteria from drinking water samples.

702 J. Microbiol. Methods 14:177-183.

703 71. Schwartz, T., S. Kalmbach, S. Hoffmann, U. Szewzyk, and U. Obst. 1998. PCR-based

704 detection of mycobacteria in biofilms from a drinking water distribution system. J.

$705 \quad$ Microbiol. Methods 34:113-123.

706 72. September, S. M., V. S. Brozel, and S. N. Venter. 2004. Diversity of nontuberculoid 707 Mycobacterium species in biofilms of urban and semiurban drinking water distribution 708 systems. Appl. Environ. Microbiol. 70:7571-7573.

709 73. Springer, B., L. Stockman, K. Teschner, G. D. Roberts, and E. C. Bottger. 1996.

710 Two-laboratory collaborative study on identification of mycobacteria: Molecular versus 711 phenotypic methods. J. Clin. Microbiol. 34:296-303.

712 74. Storey, M. V., J. Langmark, N. J. Ashbolt, and T. A. Stenstrom. 2004. The fate of 713 legionellae within distribution pipe biofilms: measurement of their persistence, 714 inactivation and detachment. Water Sci. Technol. 49:269-275.

715 75. Tamura, K., J. Dudley, M. Nei, and S. Kumar. 2007. MEGA4: Molecular evolutionary 716 genetics analysis (MEGA) software version 4.0. Mol. Biol. Evol. 24:1596-1599.

717 76. Temmerman, R., H. Vervaeren, B. Noseda, N. Boon, and W. Verstraete. 2006.

718 Necrotrophic growth of Legionella pneumophila. Appl. Environ. Microbiol. 72:4323$719 \quad 4328$.

720 77. Thompson, J. D., T. J. Gibson, and D. G. Higgins. 2002. Multiple sequence alignment 721 using ClustalW and ClustalX. Curr Protoc Bioinformatics Chapter 2:Unit 2.3. 
722 78. Torvinen, E., S. Suomalainen, M. J. Lehtola, I. T. Miettinen, O. Zacheus, L. Paulin,

723 M. L. Katila, and P. J. Martikainen. 2004. Mycobacteria in water and loose deposits of

724 drinking water distribution systems in Finland. Appl. Environ. Microbiol. 70:1973-1981.

725 79. Toze, S., L. I. Sly, I. C. Macrae, and J. A. Fuerst. 1990. Inhibition of growth of

726 Legionella species by heterotrophic plate-count bacteria isolated from chlorinated

727 drinking water. Curr. Microbiol. 21:139-143.

728 80. Turenne, C. Y., M. Semret, D. V. Cousins, D. M. Collins, and M. A. Behr. 2006.

729 Sequencing of hsp65 distinguishes among subsets of the Mycobacterium avium complex.

730 J. Clin. Microbiol. 44:433-440.

731 81. Turetgen, I., E. I. Sungur, and A. Cotuk. 2005. Enumeration of Legionella

732 pneumophila in cooling tower water systems. Environ. Monit. Assess. 100:53-58.

733 82. United States Census Bureau. 2007. Current Housing Reports, Series H150/07, p. 1-

734

735

736

737

738

739

740

741

742 642, American Housing Survey for the United States: 2007. U.S. Government Printing Office, Washington D.C.

83. United States Environmental Protection Agency. 1998. Guidance for data quality assessment-Practical methods for data analysis. Office of Research and Development, Washington, D.C.

84. Voytek, M. A., J. B. Ashen, L. R. Fogerty, J. D. Kirshtein, and E. R. Landa. 2005. Detection of Helicobacter pylori and fecal indicator bacteria in five North American rivers. J. Water Health 03:405-422.

85. Watson, C. L., R. J. Owen, B. Said, S. Lai, J. V. Lee, S. Surman-Lee, and G. Nichols. 2004. Detection of Helicobacter pylori by PCR but not culture in water and biofilm 
samples from drinking water distribution systems in England. J. Appl. Microbiol. 97:690-698.

86. Whan, L., H. J. Ball, I. R. Grant, and M. T. Rowe. 2005. Occurrence of Mycobacterium avium subsp paratuberculosis in untreated water in Northern Ireland. Appl. Environ. Microbiol. 71:7107-7112.

87. Wullings, B. A., and D. van der Kooij. 2006. Occurrence and genetic diversity of uncultured Legionella spp. in drinking water treated at temperatures below 15 degrees C. Appl. Environ. Microbiol. 72:157-166. 
Table 1. Primer Sequences, References and PCR Conditions.

\begin{tabular}{|c|c|c|c|}
\hline $\begin{array}{c}\text { Target } \\
\text { (Reference) }\end{array}$ & Sequence & $\begin{array}{l}\text { Product } \\
\text { size }\end{array}$ & PCR Conditions \\
\hline $\begin{array}{l}\text { 16S RNA gene } \\
\text { Legionella spp. } \\
\text { (87) }\end{array}$ & $\begin{array}{c}\text { LEG-225 5'AAGATTAGCCTGCG } \\
\text { TCCGAT; LEG-858 5'GTCAACT } \\
\text { TATCGCGTTTGCT }\end{array}$ & $656 \mathrm{bp}$ & $\begin{array}{c}94^{\circ} \mathrm{C} 2 \min (1 \text { cycle }) ; 94^{\circ} \mathrm{C} \\
20 \mathrm{sec}, 60^{\circ} \mathrm{C} 30 \mathrm{sec}, 72^{\circ} \mathrm{C} \\
40 \mathrm{sec}(40 \text { cycles }) ; 72^{\circ} \mathrm{C} 5 \\
\min (1 \text { cycle })\end{array}$ \\
\hline $\begin{array}{l}\text { 16S RNA gene } \\
\text { Mycobacterium } \\
\text { spp. (13) }\end{array}$ & $\begin{array}{c}\text { MycgenF 5' AGAGTTTGATCCT } \\
\text { GGCTCAG; MycgenR 5' TGCAC } \\
\text { ACAGGCCACAAGGGA }\end{array}$ & $1,030 \mathrm{bp}$ & $\begin{array}{c}95^{\circ} \mathrm{C} 2 \min (1 \text { cycle }) ; 93^{\circ} \mathrm{C} \\
1 \mathrm{~min}, 60^{\circ} \mathrm{C} 1 \mathrm{~min}, 72^{\circ} \mathrm{C} 1 \\
\min (35 \text { cycles }) ; 72^{\circ} \mathrm{C} 5 \\
\min (1 \text { cycle })\end{array}$ \\
\hline $\begin{array}{l}\text { 16S RNA gene } \\
\text { Helicobacter } \\
\text { spp. (34) }\end{array}$ & $\begin{array}{l}\text { HS1 5' AACGATGAAGCTTCT } \\
\text { AGCTTGCTAG; HS2 5' GTGCT } \\
\text { TATTCGTTAGATACCGTCAT }\end{array}$ & $400 \mathrm{bp}$ & $\begin{array}{c}94^{\circ} \mathrm{C} 5 \min (1 \text { cycle }) ; 94^{\circ} \mathrm{C} \\
1 \mathrm{~min}, 65^{\circ} \mathrm{C} 1 \text { min, } 72^{\circ} \mathrm{C} 1 \\
\min (35 \text { cycles }) ; 72^{\circ} \mathrm{C} 5 \\
\min (1 \text { cycle })\end{array}$ \\
\hline $\begin{array}{l}\text { 16S RNA gene } \\
\text { Eubacteria ( } 84)\end{array}$ & $\begin{array}{c}\text { 46f 5' GCYTAACACATGCA } \\
\text { AGTCGA; 519r 5' GTATTACCG } \\
\text { CGGCKGCTG }\end{array}$ & $490 \mathrm{bp}$ & $\begin{array}{c}95^{\circ} \mathrm{C} 5 \mathrm{~min}(1 \text { cycle }) ; 94^{\circ} \mathrm{C} \\
0.5 \mathrm{~min}, 56^{\circ} \mathrm{C} 0.5 \mathrm{~min}, \\
72^{\circ} \mathrm{C} 1.5 \mathrm{~min}(30 \text { cycles }) \\
72^{\circ} \mathrm{C} 7 \text { min }(1 \text { cycle })\end{array}$ \\
\hline
\end{tabular}


Table 2. Range and Arithmetic Mean of HPC bacteria, total coliforms, and E. coli

\begin{tabular}{|c|c|c|c|}
\hline \multirow[b]{2}{*}{ Bacteria } & \multirow[b]{2}{*}{ Measurement } & \multicolumn{2}{|c|}{ Source } \\
\hline & & $\begin{array}{l}\text { Treated Municipal } \\
\qquad(\mathrm{n}=16)\end{array}$ & $\begin{array}{c}\text { Groundwater Well } \\
(\mathrm{n}=41)\end{array}$ \\
\hline \multicolumn{4}{|l|}{ Heterotrophic plate counts } \\
\hline \multirow{2}{*}{ In first flush (CFU/ml) } & Range & $*$ & $1.5 \times 10^{0}-5.12 \times 10^{7}$ \\
\hline & Arithmetic Mean & $*$ & $2.81 \times 10^{6}$ \\
\hline \multirow[t]{2}{*}{ In water $(\mathrm{CFU} / \mathrm{ml})$} & Range & $3.57 \times 10^{2}-5.15 \times 10^{5}$ & $2.0 \times 10^{0}-9.23 \times 10^{5}$ \\
\hline & Arithmetic Mean & $9.02 \times 10^{4}$ & $5.7 \times 10^{4}$ \\
\hline \multirow[t]{2}{*}{ In biofilm $\left(\mathrm{CFU} / \mathrm{mm}^{2}\right)$} & Range & $<1-1.24 \times 10^{5}$ & $<1-3.22 \times 10^{5}$ \\
\hline & Arithmetic Mean & $1.79 \times 10^{4}$ & $4.29 \times 10^{4}$ \\
\hline \multicolumn{4}{|l|}{ Total Coliforms } \\
\hline \multirow[t]{2}{*}{ In first flush (CFU/100ml) } & Range & $*$ & $<1-1.19 \times 10^{3}$ \\
\hline & Arithmetic Mean & $*$ & $1.17 \times 10^{2}$ \\
\hline \multirow[t]{2}{*}{ In water (CFU/100ml) } & Range & $<1-2.63 \times 10^{1}$ & $<1-2.96 \times 10^{3}$ \\
\hline & Arithmetic Mean & $2.71 \times 10^{0}$ & $1.07 \times 10^{2}$ \\
\hline \multicolumn{4}{|l|}{ Escherichia coli } \\
\hline \multirow[t]{2}{*}{ In first flush (CFU/100ml) } & Range & $*$ & $<1$ \\
\hline & Arithmetic Mean & $*$ & $<1$ \\
\hline \multirow[t]{2}{*}{ In water (CFU/100ml) } & Range & $<1$ & $<1-2.22 \times 10^{2}$ \\
\hline & Arithmetic Mean & $<1$ & $5.68 \times 10^{0}$ \\
\hline
\end{tabular}

* No samples were taken in this category. 
Table 3. Statistical Analysis of the Interactions between HPC Bacteria in Drinking Water and Response Variables

\begin{tabular}{cccc}
\hline & & \multicolumn{2}{c}{ Significance and FDR } \\
\cline { 3 - 4 } Response Variable & Model & $P$ & $P_{(12)}$ \\
\hline Helicobacter $(\mathrm{BF})$ & Binary Logistic Regression & 0.95 & 0.100 \\
Mycobacteria $(\mathrm{BF})$ & Binary Logistic Regression & 0.778 & 0.092 \\
Helicobacter (System) & Binary Logistic Regression & 0.628 & 0.083 \\
Total coliforms (DW) & Simple Linear Regression & 0.463 & 0.075 \\
Helicobacter $(\mathrm{DW})$ & Binary Logistic Regression & 0.457 & 0.067 \\
Legionella $(\mathrm{DW})$ & Binary Logistic Regression & 0.068 & 0.058 \\
Mycobacteria $(\mathrm{System})$ & Binary Logistic Regression & $0.044^{*}$ & 0.050 \\
Mycobacteria $(\mathrm{DW})$ & Binary Logistic Regression & $0.03^{*}$ & 0.042 \\
Escherichia coli $(\mathrm{DW})$ & Simple Linear Regression & $0.026^{*}$ & 0.033 \\
HPC bacteria $(\mathrm{FF})$ & Paired t-test & $0.025^{*}$ & 0.023 \\
Legionella (System) & Binary Logistic Regression & $0.003^{*}$ & 0.017 \\
Legionella $(\mathrm{BF})$ & Binary Logistic Regression & $0.001^{*}$ & 0.008 \\
\hline
\end{tabular}

* Denotes P-value with statistical significance.

(FDR) false discovery rate, (FF) first flush, (BF) biofilm, (DW) drinking water, (System) combines all sample fractions. 
Table 4. Statistical Analysis of the Interactions between HPC Bacteria in Biofilms and Response Variables

\begin{tabular}{cccc}
\hline & & \multicolumn{2}{c}{ Significance and FDR } \\
\cline { 3 - 4 } Response Variable & Model & $P$ & $P_{(10)}$ \\
\hline Helicobacter $(\mathrm{BF})$ & Binary Logistic Regression & 0.872 & 0.100 \\
Helicobacter $(\mathrm{DW})$ & Binary Logistic Regression & 0.746 & 0.082 \\
Helicobacter $($ System) & Binary Logistic Regression & 0.726 & 0.073 \\
Total coliforms $(\mathrm{DW})$ & Simple Linear Regression & 0.606 & 0.064 \\
Mycobacteria $(\mathrm{DW})$ & Binary Logistic Regression & 0.509 & 0.055 \\
Legionella $(\mathrm{BF})$ & Binary Logistic Regression & 0.204 & 0.045 \\
Legionella $(\mathrm{DW})$ & Binary Logistic Regression & 0.208 & 0.036 \\
Legionella $($ System $)$ & Binary Logistic Regression & 0.185 & 0.027 \\
Mycobacteria $(\mathrm{BF})$ & Binary Logistic Regression & 0.051 & 0.018 \\
Mycobacteria (System) & Binary Logistic Regression & 0.01 & 0.009 \\
\hline
\end{tabular}

(FDR) false discovery rate, (BF) biofilm, (DW) drinking water, (System) combines all sample fractions.

Table 5. Statistical Analysis of the Interactions between Drinking Water Source (Treated Municipal or Groundwater Well) and Response Variables

\begin{tabular}{cccc}
\hline & & \multicolumn{2}{c}{ Significance and FDR } \\
\cline { 3 - 4 } Variable & Model & $P$ & $P_{(7)}$ \\
\hline Escherichia coli $(\mathrm{DW})$ & Two sample t-test & 0.418 & 0.100 \\
Helicobacter $($ System) & Fisher's exact test & 0.393 & 0.086 \\
Mycobacteria $($ System) & Fisher's exact test & 0.216 & 0.071 \\
HPC bacteria (DW) & Two sample t-test & 0.13 & 0.057 \\
Total coliforms (DW) & Two sample t-test & 0.128 & 0.043 \\
HPC bacteria (BF) & Two sample t-test & 0.049 & 0.029 \\
Legionella $($ System) & Fisher's exact test & $0.003^{*}$ & 0.014 \\
\hline
\end{tabular}

* Denotes P-value with statistical significance.

(FDR) false discovery rate, (BF) biofilm, (DW) drinking water, (System) combines all sample fractions. 


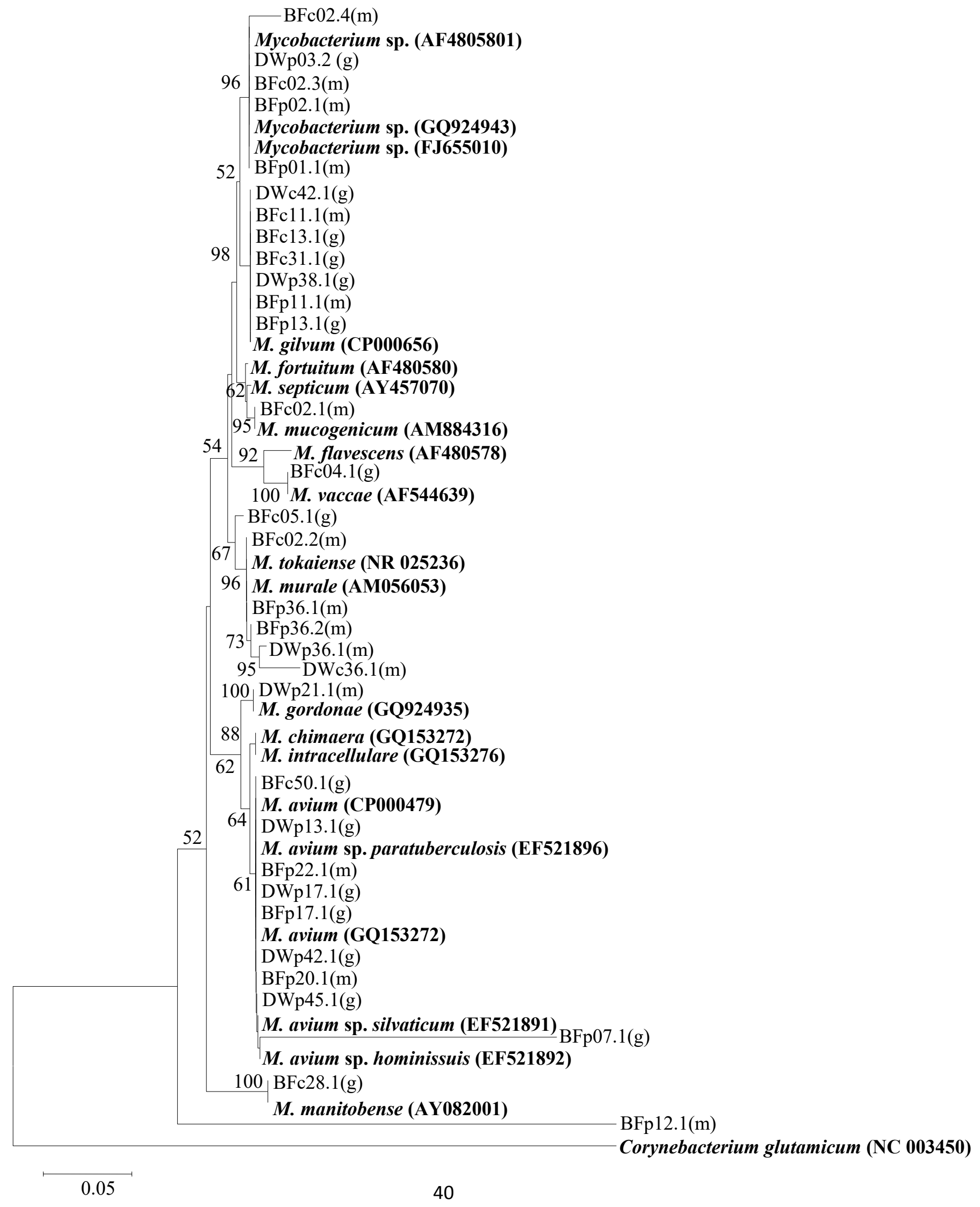


Figure 1. Phylogenetic relationship of 16s rRNA gene amplified with Mycobacterium genusspecific primers with Corynebacterium glutamicum as the out-group. Reference sequences are in bold with accession numbers in parentheses. Sequences from this study are indicated by code as follows. (DW) drinking water, (BF) biofilm, (p) PCR, (c) culture, (g) groundwater, and (m) municipal. 


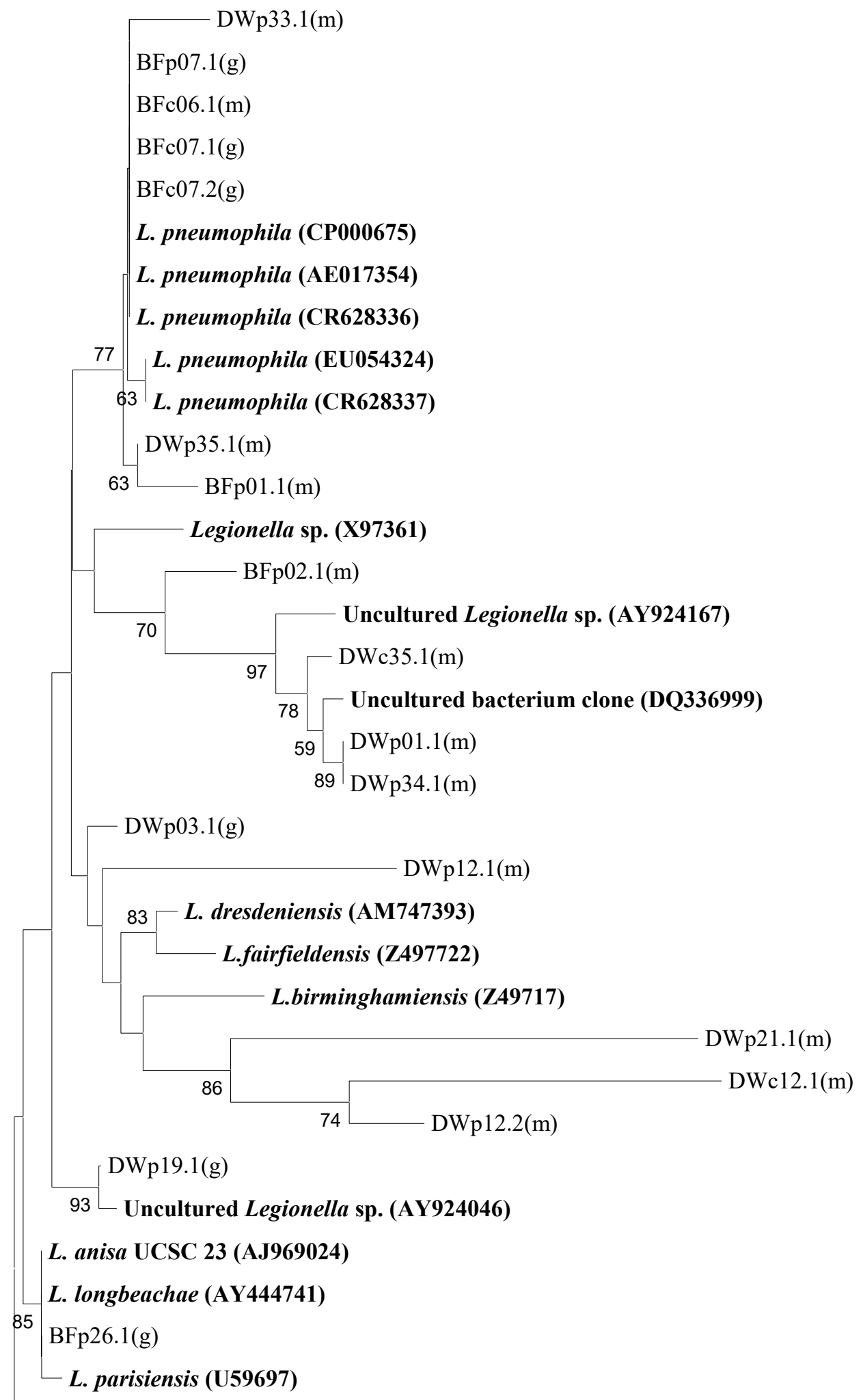

Coxiella burnetii (AE016828) 
Figure 2. Phylogenetic relationship of 16s rRNA gene amplified with Legionella genus-specific primers with Coxiella burnetii as the out-group. Reference sequences are in bold with accession numbers in parentheses. Sequences from this study are indicated by code as follows. (DW) drinking water, (BF) biofilm, (p) PCR, (c) culture, (g) groundwater, and (m) municipal.

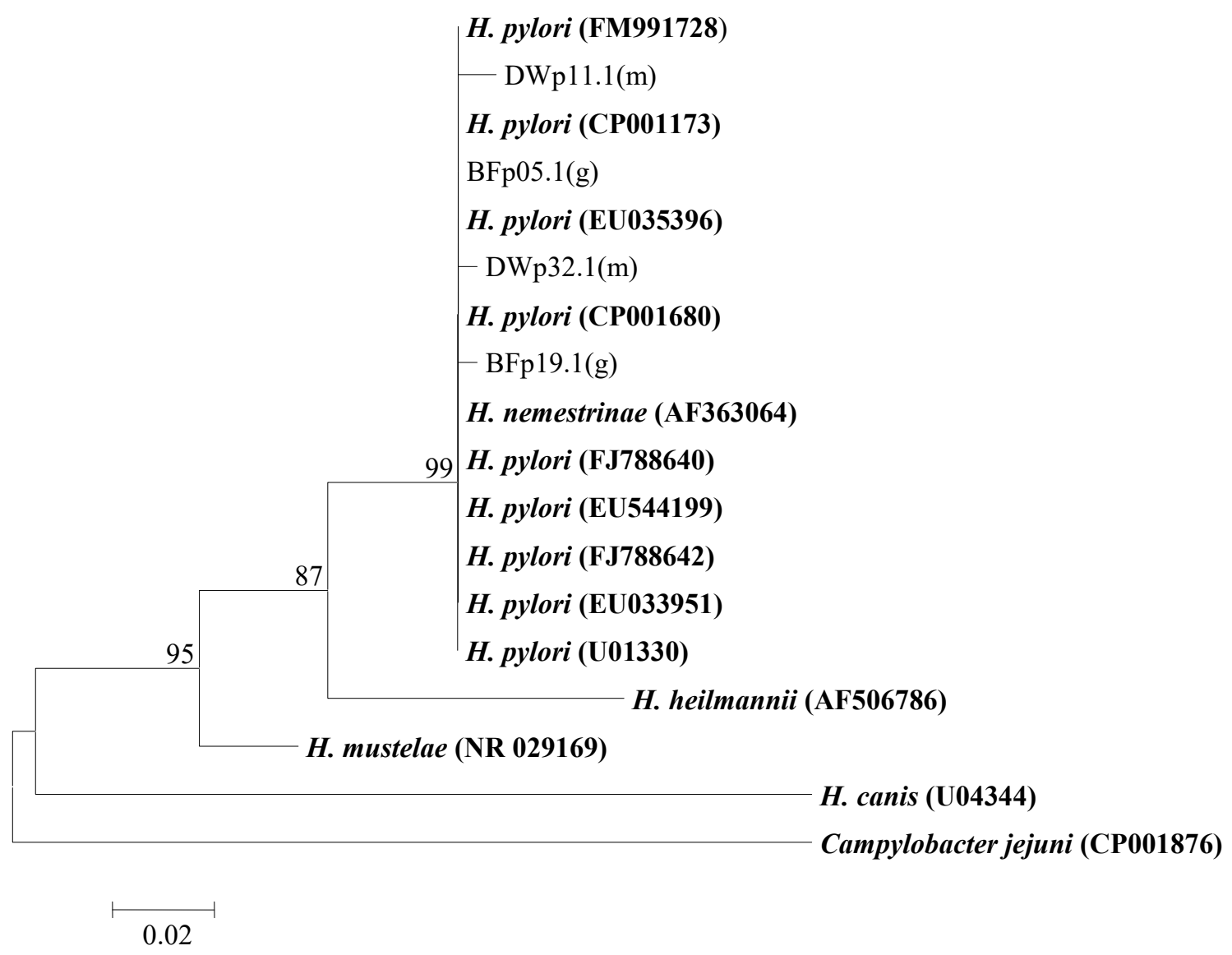

Figure 3. Phylogenetic relationship of 16s rRNA gene amplified with Helicobacter genusspecific primers with Campylobacter jejuni as the out-group. Reference sequences are in bold with accession numbers in parentheses. Sequences from this study are indicated by code as follows. (DW) drinking water, (BF) biofilm, (p) PCR, (c) culture, (g) groundwater, and (m) municipal. 